raphy-and nearly three hundred pen-andink sketches in the text.

No expense or care was spared in the execution of the work; some thirty scientific men and art specialists, both in Europe and in America, were engaged to contribute their views upon various aspects of the whole subject; and the illustrations were prepared in the finest manner possible, Chinese and Japanese artists being employed to execute many of them, and color experts being freely consulted, under the supervision of Mr. Bishop himself. The catalogue has, moreover, a special value from the fact that all the scientific investigations described therein were made upon material taken from the specimens in the collection itself.

This whole work, from its inception by Mr. Bishop in 1886 to the final distribution of the volumes, has required about twenty years, and was entirely planned and thought out by him. It is a cause of much satisfaction that the enterprise has been so fully and successfully completed along the lines which he laid down; but it is also a source of profound regret that he could not himself have lived to witness its final accomplishment. The whole cost has been met by the liberality of Mr. Bishop's provision, carried out by the care and thoughtfulness of his executors.

Attendance at the meetings of the section was discouragingly small, there being but seven geologists present during the whole time of the association meeting, and two of these did not arrive until after the adjournment of the section.

The foregoing account of the meeting has been prepared from the full notes kept by the secretary pro tem.

$$
\begin{aligned}
& \text { Edmund Otis Hovey, } \\
& \text { Secretary. }
\end{aligned}
$$

american Museum of Natural History.

\section{MORPHOLOGY AND PHYLOGENY.'}

$\mathrm{WE}$ are at the present time passing through a season of morphological thaw. The doctrine of definite and fixed morphological types has been somewhat slower than that of the fixity of species, in melting under the fierce light, which beats on all scientific generalizations; but its disappearance has not been less final or less complete. This breaking up of the ice of morphological formalism, which has so long needlessly restrained the course of morphological and phylogenetic research, is not altogether unattended with the dangers which accompany the opening of a new spring. On the part of some there is fear or even hope, that not only the ice, but the banks of the river as well, will be swept away by the raging flood. There is, however, no more need to dread the final result for phylogeny, than there was to fear the disappearance of the doctrine of fixity of species, half a century ago, as subversive to taxonomy. On the contrary, we may reasonably expect that, as in the case of the sister science, morphology and phylogeny will in the long run vastly benefit by getting rid of the constraint of mere formalism.

It is now more than a generation since any considerable number of biologists has believed that species were created once and for all, and unchangeable until they became extinct. At the present time this doctrine enjoys scarcely even a pagan persistence in some of our more belated schools of learning. Whatever may be our individual views in regard to the doctrine of descent or evolution, we are in general agreed that species are derived by modification and change from previous species and not by a special creative fiat. This conclusion, as Darwin pointed out many years ago, in his 'Origin of Species,' is at bottom a mor-

\footnotetext{
${ }^{1}$ Presidential address delivered before the Society for Plant Morphologr. Ann Arbor, December $29,1905$.
} 
phological one. Since the appearance of the 'Origin of Species,' we have had developed, particularly in the realm of plants, the conceptions of the special science of ecology or epharmony. The rapid growth of this science has led to the clear realization of how remarkably the external form of plants may be assimilated by similar modes of life. Later still is the appearance in a pronounced form of the doctrine of mutational or saltatory evolution of species. The establishment of these two new disciplines, both having firm scientific foundations, has tended to weaken the hold of morphology on the scientific mind. For if the form of plants may be instantly and profoundly modified by the still occult process of mutation, or more slowly but not less surely by the more obvious influence of external conditions, then it is not unnatural that less importance should be attached to form and structure, which are the subject matter of morphology. And yet the doctrine of descent, the great outstanding generalization of the biological sciences, which few of us probably expect to see overthrown, is bound up with the integrity of the science of morphology. The doctrine of descent or phylogeny depends for its validity on the correctness of the inference that marked similarities of structure indicate a more or less close degree of relationship. In the existing situation, the new studies of ecology and mutation, still in the first gloss of their novelty, tend to outshine the older yet not less firmly founded science of morphology, which through lapse of time has suffered as it were a certain degree of surface tarnish. Newer aspects of morphology are, however, coming to light at the present time, which promise to restore to the subject all its former brilliancy. It is my intention this morning to give some brief account of these new developments.

A prevailing principle in the past in morphology has been to trace back organs or tissue-systems to a similar mode of origin from the growing point or young organ and hence to infer their morphological equivalence. Thus, for example, the morphological essence of a sporangium has been thought to exist in the possibility of deriving its sporogenous tissue from a clearly defined and early developed primordium known as the archesporium. Similarly the morphological value of the central cylinder or fibrovascular system of the higher plants is thought by many morphologists to depend on its origin at the growing-point of the organ, root, stem or leaf, from that so-called primary meristem, known as the plerome. In the case of the sporangium, the illuminating researches of Professor Bower have made it clear that not only may spore-producing cells arise outside the so-called archesporium, as in Equisetum, but also sterile or asporogenous tissues may originate from mother cells apparently destined to form spores, as in Tmesipteris and Isoetes. In the case of the sporangium, it is accordingly clear that its fundamental characteristic is that it produces spores and not that its sporogenous tissue originates from an archesporium. There ean be no doubt whatever that in the vascular plants a spore is to be regarded as morphologically a spore, whether its mother cell comes from the so-called archesporial complex or not. In the case of the central cylinder of stele, the clash of many minds has not yet resulted in a similar general clarity of reasoning. If we, for example, choose the case of the central cylinder of the root in the Angiosperms, which the recent very exact researches of Schoute show to be derived definitely and entirely from the plerome strand of the growing-point, we have a result which is in so far satisfactory from the standpoint of the older morphology. If we, however, proceed to the consideration 
of the mode of origin of the secondary roots from such a root, we find that they are formed in all their parts, entirely within the central cylinder or plerome strand of the mother root. We have thus the cortex and piliferous layers of the daughter root, which are properly the derivatives of the apical meristems known as the periblem and the dermatogen, and not of the plerome, originating in this case from the plerome or its equivalent. A logical fallacy thus arises, if we regard the morphological value of the tissue-systems of the root as determined from the meristems from which they take their origin. Further, if we take the case of the stem of the Pteridophyta, where alone among stem organs, the so-called apical meristems can in general be somewhat clearly distinguished, we reach equally illogical conclusions. Let us, for example, follow certain recent writers in regarding the whole complicated fibrovascular system of the rootstock of the common bracken fern, Pteris aquilina, together with its interposed ground tissue, as constituting a single hypothetical circular stele or central cylinder, because all these tissues are derived from the plerome strand of the growing end of the rhizome. If in all cases the plerome were as generously large as it is in Pteris aquilina and sufficiently broad to include the fibrovascular strands, together with their interposed fundamental tissue, we might successfully sustain the thesis that there is but one central cylinder and the plerome is its prophet. Unfortunately, however, in some cases the plerome proves to be a misfit and is smaller than the central cylinder, which it should entirely include. As a result in some of the true ferns, essential tissues of the fibrovascular bundles, such as the pericycle, the phloem and even part of the tracheary tissues are left in outer morphological darkness, because they do not originate from the plerome, but from the periblem. In a recently published work, Professor Campbell even states that in the mature stem of Equisetum only the pith is formed from the plerome, all of the fibrovascular tissues being left outside. $\mathrm{He}$ concludes that in Equisetum the fibro-vascular bundles do not form a part of the central cylinder. This is surely Hamlet with Hamlet left out, and may perhaps stand as the reductio ad absurdum of growing-point morphology. If our not very remote posterity compare our speculations in regard to the morphological value of the growing point in plants, with those well-known discussions of medieval doctors as to the number of angels who might successfully stand on the point of a needle, our neglect of logic will probably not appear less absurd than their entire disregard of facts.

The two examples just discussed sufficiently illustrate the present condition of transition in morphology. Although the ancient doctrine of preformation has long been consigned to the limbo of oblivion, it has nevertheless a disguised survival in the hypothesis that the organs of tissue-systems of the higher plants can definitely be traced back to an origin from certain definite primordia. This hypothesis appears destined to become as obsolete in morphology as that of predestination is in theology. We have in fact arrived at that stage in morphological enlightenment where, with the complete abandonment of all obscurantism; we call a spade a spade, meaning by a spade that which performs or has performed the functions of a spade. Nothing appears clearer in the present stage of our knowledge than that with Professor Goebel we must regard the organ as the tool or apparatus of a function and the organism as a complex of apparatus combining a number of functions. Yet even if it be true that the organ is but the tool 
or apparatus of the function, it by no means follows, as is too often assumed, that morphology disappears as such and becomes merged with physiology. The methods of nature are economical in the extreme, and when she needs a ploughshare, she fashions it from a no longer useful sword, or if a pruning hook be required, she straightway makes it from a spear, without in either case too carefully obliterating the signs of former use. By reason of this fact, with changing conditions, the apparatus of obsolete functions is not cast aside and replaced by other apparatus constructed anew to suit the new functional demand, but is merely modified more or less profoundly for the new duty. This makeshift character of organs is the solid basis of morphology. Morphology thus takes cognizance of the conservative tendencies which inhere in form and structure, and is clearly separated from physiology which deals with the actual functions alone and their apparatus.

Since the conservatism which inheres in the form and structure of plants is the peculiar province of plant morphology, it can not afford to neglect the earlier and extinct vegetation which once peopled the earth. Almost until the present moment botanical morphology has labored, however, under a peculiar disadvantage in this respect. In the case of fossil vertebrated animals, which may be appropriately compared with vascular plants, the processes of decay, which accompany fossilization, only serve to make the skeletal tissues, morphologically the most important, stand out the more clearly, so that they thrust themselves, as it were, on the gaze of the beholder and thus at once suggest comparison with the similar structures of animals still living. You are all aware of the extremely important advances made in the earliest third of the last century by the great French anatomist Cuvier in the study, particularly of the vertebrate skeleton. Since the publication of his 'Ossemens Fossiles' and his 'Regne Animal,' there has aways been on the part of the zoologists a sufficient attention to the morphological and phylogenetic significance of the hard parts of animals, which are fortunately not only morphologically constant, but also extraordinarily resistent to decay. In the case of plant fossils the conditions have unhappily not been so favorable. Although it has been realized, especially in recent years, that the adaptations to environment, which so quickly affect the outward form of plants, act with extreme slowness on their fibrovascular skeleton, comparatively little advantage to morphology has resulted. Vegetable fossils, during the process of fossilization, are more subject to the ravages of decay than are those of animals, and the decay is generally not of such a character as to set their skeletal and morphologically important parts in strong relief. Indeed it is very frequently these parts which suffer first, owing to the fact that they do not often contain the antiseptic substances which are generally present in the softer tissues. Thus, for example, if it were not for the remains of the leaves of dicotyledonous plants in the Cretaceous, we should have little evidence for the occurrence of the Angiosperms at so early a-geological epoch. The only relics of dicotyledonous woods which have come down to us are those somewhat rare ones of the upper Cretaceous which have been carbonized by fire. Thus in the Raritan beds there are quantities of dicotyledonous charcoals, but no remains of wood in the lignitic or other ordinary conditions of fossilization. Fven when plant remains do show the very significant hard tissues preserved, the microscope is generally necessary for their diagnosis. Plant fossils then, if we excent fossil leaves, do not ordinarily pre- 
sent the significant structures in such a form that he who collects may read. For this reason large quantities of valuable material have been in the past thrown aside by the paleontological collector as undiagnosable. The skill of the lapidary too has often to be brought into play, before it becomes possible to satisfactorily identify a vegetable fossil or detect its affinities. This state of affairs has brought it about, that no such important results flowed from the labors of the great French paleobotanist, Brongniart, as from those of his more fortunate zoological contemporary Cuvier. Indeed such anatomical observations as were made by Brongniart and his more immediate followers were so misleading that they resulted in the conclusion that secondary woody growth was a phanerogamic character and consequently the mistake was made of putting the calamites and sigillarians with the gymnosperms and not with their real affinities the horsetails and clubmosses. This error proved to be very tenacious of life and was only finally overthrown towards the end of the last century.

The cheapening and improvement of all kinds of apparatus, which is one of the most gratifying features of modern scientific progress, has made it possible in the last decade or two to satisfactorily begin the investigation of the past history of the higher plants. Out of this study of the structure of the more ancient vascular plants, especially when carried on by those adequately equipped for such a task, by the knowledge of the anatomical structure of allied plants still living, have emerged a number of important general morphological principles, which are destined to have an influence on the development of botanical morphology and phylogeny, not less important than the investigation of Cuvier, in the last century, on fossil animals, have had on zoology.
One of these important general principles, namely, the repetition of phylogeny in ontogeny is not confined to plants, but has had few exemplifications heretofore on account of the fact that our knowledge of the past history of the vegetable kingdom has been so woefully meager. Of this principle one example will suffice. The researches of the paleobotanists have made us acquainted with the structure of a paleozoic transitional group of gymnosperms, the Medullosæ. These had the numerous concentric stem-bundles of many existing ferns, but differed from these in the fact that their bundles had secondary growth. Their anatomical structure otherwise strongly suggests the cycads, and Potonie has expressed in fact the opinion that the existing cycads have come from this fossil stock. This view has recently received a remarkable confirmation by the discovery of the French anatomist Matte, that in certain instances in the seedling of the living cycadean genus Zamia, concentric bundles resembling those of the Medullosæ are present. Many other similar examples might be cited from recent literature.

Perhaps the most important and most novel general principle which has resulted from the comparative study of living and fossil vascular plants is the elucidation of the tendency of ancestral characteristies to persist strongly in the reproductive axis or flowering stem. For example, it has been pointed out by Graf zu Solms that the arrangement and course of the departing foliar traces in the cycads is not of the complex type found in the vegetative stem of the living genera of that group, but of the simple type occurring in the leafy stem of the ancient cycadoidean stock, the Bennettitales. Dr. Scott has added to this the important observation that in certain cases the structure of the bundles of the cycadean reproductive axis resem- 
bles that found in the vegetative stems of some of the very ancient Cycadofilices. Similarly the present speaker has observed that the structure of the woody axis of the cone in living species of Pinus differs strikingly from that found in the vegetative stem, and strongly resembles that found in Cretaceous Pityoxyla. This important principle of the persistence of ancestral features in reproductive axes is particularly significant, because it offers an independent support for the time-honored practise of the systematic botanist, who attaches great importance to the floral structures and their arrangements, in tracing lines of affinity in the flowering plants.

Another important new phylogenetic principle, which has recently emerged, and which is likewise the special property of the botanical morphologist, is that ancestral characters are extremely likely to persist as structural features of the leaf. For example, the leaf-bundles of the cycadean gymnosperms are the exact counterpart of the stem-bundles of some of the extinct and probably ancestral Pteridospermæ. This principle might also be illustrated by many examples if time permitted.

We have thus three important phylogenetic laws resulting from our more complete knowledge of the older vegetation of the earth. These principles or laws having been elucidated by the comparison of living with fossil forms may now fruitfully be extended as general working rules to the comparison of living groups with one another. The importance of these principles can scarcely be overestimated; for they enable us at once to put the sporophytic generation in the foreground as the basis of phylogenetic study. This is particularly fortunate, because it is precisely the sporophyte which allows fruitful comparison with extinct forms, since the gametophyte does not ordinarily become fossilized. Moreover, since the time of Hofmeister, the gametophytic generation has performed such an important rôle in morphological investigations that in recent years, in spite of the important discoveries of chalazogamy, the antherozoids of the cycads and Ginkgo, and double fertilization in the angiosperms, it has begun to show signs of exhaustion. The next half century, without neglecting the gametophyte or the earlier stages of the sporophyte, will doubtless give a great deal more attention to the later development and mature structure of the sporophyte, which being the predominating and unreduced generation, in the vascular plants, will yield, as our knowledge of the ancient forms becomes more complete, the most important morphological and phylogenetic results.

A further fruitful field for morphological exploitation is that of experimental morphology. This field, although much discussed and canvassed at the present moment, is as yet practically untouched from the phylogenetic side. It is diffcult to see how it can be successfully cultivated by those who have not a reasonably complete knowledge of what may be called the normal anatomy of living and fossil plants. We appear as yet to be no nearer to the possibility of experimentally originating new species. Indeed, if we ever succeed in penetrating the veil with which nature conceals this part of her workings, the hypothesis that acquired characters can not be transmitted will have to be given up. For if by experiment we are able to bring it about that species acquire and transmit new characters and thus become new species, the doctrine of the non-transmission of acquired characters will become ipso facto obsolete.

In conclusion, it may be said that there appears to be no immediate prospect that the practise of making genealogical or phylogenetic trees will have to be abandoned. In constructing these trees, however, we 
shall do well to avoid inferences as to relationship based on a single character. Phylogenies of the angiosperms based on the structure of the root-tip, or of the conifers on the supposed occurrence of a ligule in the Araucarineæ, or of the Pteridophyta derived from the presence or absence of a suspensor in the embryo or a basal cell in the archegonium, have in the past been far too common. We morphologists have sinned the sins of youth in this respect and have often provoked the just censure of the taxonomists. We must avoid, too, the using, for phylogenetic purposes, of characters which can be easily modified by environment, in other words characters which are formal or physiological. In making our phylogenetic trees, as Professor Coulter has recently happily expressed it, we have begun with the topmost branches and then have followed downward into the trunk. May we successfully continue this downward progress, so that in the fullness of time our perfect tree may stand firmly rooted in the earth, drawing strength and nourishment from every stratum which contains a vestige of the former vegetation of the world. E. C. JEFFREY.

HARVARD UNIVERSITY,

Cambridgie, Mass.

\section{THE AFFILIATION OF PSYCHOLOGY WITH PHILOSOPHY AND WITH THE NAT- URAL SCIENCES. ${ }^{1}$}

I AM embarrassed that this discussion of

${ }^{1}$ This was the topic on the program of the joint meeting of the Philosophical and Psychological Associations at Harvard, December 27, 1905. The introductory exercises of this session consisted in dedicating the new Emerson Hall with addresses by President Eliot, Dr. Emerson and Professor Münsterberg. The last named opened the discussion of the above question by arguing that philosophy and psychology, now under one roof, should be one and inseparable. The address here printed follows exactly as it was given except that part of the first paragraph was spoken in the discussion at the end. the relations between philosophy and psychology immediately follows the exercises which have so emphatically and reiteratedly pronounced them one. I had written my brief paper purposely in a slightly more partisan than judicial spirit because asked to represent one side, and informed that others would represent the other. I had no idea, however, that I must read just at a moment which makes me seem to be trying to put asunder what Harvard has just now joined together. Objections to marriages are usually called for before the ceremony itself, and I almost feel that the proprieties of the hour should make me hold my peace here, though not forever afterwards. I feel like a divorce lawyer, thrusting his professional card into the hands of a wedded pair before they have left the church. However, the hospitality of our hosts will be, I am sure, more than adequate, and of course there was no thought of projecting the momentum of this occasion into the discussion to place my side of it at a disadvantage. At least, I will assume that the program takes precedence over any such proprieties and proceed with what I have written, which is as follows :

To me it seems only a truism to say that we do not and, perhaps, never can know any more of the ultimate nature, origin and destiny of the soul than we can and do of the nature, origin or destiny of matter or of life. In this sense psychology may do very well for the present without a soul as physics may do without an ultimate definition of force, or biology without a theory of life. This, moreover, is a positive and gnostic and not an agnostic standpoint except to those who place metaphysics, meta-biology or meta-psychology above these sciences themselves. Definitions of our science and even of each sense of will, cognition, feeling and the rest, may, perhaps, be divided into the following 